\title{
TITLE:
}

\section{A Wenner-Gren Symposium: WENNER-GREN LIMERICKS}

\author{
$\operatorname{AUTHOR}(\mathrm{S}):$ \\ Tutin, Caroline
}

\section{CITATION:}

Tutin, Caroline. A Wenner-Gren Symposium: WENNER-GREN

LIMERICKS. Pan Africa News 1995, 2(1): 12-12

\section{ISSUE DATE:}

1995-06

URL:

http://hdl.handle.net/2433/143310

\section{RIGHT:}

Copyright (C) Pan Africa News. 


\title{
WENNER-GREN LIMERICKS
}

\author{
by Caroline Tutin
}

We all came here thanks to sydel

our interesting stories to tell

She 1istens to each

But keeps within reach

Her warning, anthropological, bell

Our leader is named Bill McGrew

And he chose an agreeable crew

To Cabo we came

To join in his game

Success of all kinds will accrue

Dr Jane she was here and then gone

En route for Alaska - so long

We're glad that she fights

With all of her might

To save chimps from here to Hong Kong

Mahale, a magical place

Is where Toshi, with unfailing grace,

Has studied the chimps

They're fighters not whimps

coalitions avoid loosing face

Dr Kano is quiet and wise

The bonobo sexual surprise

He revealed with a smile

But it took quite a while

To place this behavioural prize

Dr Wrangham was Madingley's best

But he climbed on a plane and flew west

For he could well see

That high grade THV

Grew greener by far in US

A young lady called Fruth moves so fast She climbs up both trees and boat masts To get to those nests

She gives of her best

And I bet that she' 11 never be last

A Dutch girl named Iottie likes lots

of acquisitive baby robots

And what is the theory?

That we should be leery

of attributes like intention....or not?
Wamba was the place Suehisa got With bonobos dense at this spot He got off the fragile bike

Preferring to hike

And so data came such a lot!

This brings us to Diane Doran Who's studied Gorilla and Pan

Apart and sympatric

She details the antics

That differ from bipedal Man

Young John gives a real mean pant hoot

And throws in a long call to boot

But when he gives belch grunts

We all know that more stunts

Like parties will soon follow suit

A chimpanzee lady named Ai

A natural experiment try

She trained Matuzawa

Fine objects to show her

For pleasure of hand, mind and eye

A politically correct man, Frans

Showed a great passion for dance

But is it aggressive,

Passive or submissive

or just letting off steam, quite by chance

I'homme de la forêt, Christophe Who never will beat round the bush

Watched Taï chimps use tools

And break all the rules

with their drumming and colobus butch (ering)

There is a young lass from Lopé

Who follows gorillas each day

DBH is her measure

Sieving jobbies her pleasure

As she makes up her limericks risque 